\title{
Adult Education in a Transnational Space: The Status of Adult Education in Norway and Spain
}

\author{
Christin Tønseth¹, Emilio Lucio-Villegas ${ }^{2}$ \\ ${ }^{1}$ Department of Education and Lifelong Learning, Norwegian University of Science and Technology, Trondheim, Norway \\ ${ }^{2}$ Department of Theory and History of Education and Social Pedagogy, Faculty of Education Science, University of Sevilla, \\ Sevilla, Spain \\ Email: christin.tonseth@.ntnu.no, elucio@us.es
}

How to cite this paper: Tønseth, C., \& Lucio-Villegas, E. (2019). Adult Education in a Transnational Space: The Status of Adult Education in Norway and Spain. Creative Education, 10, 882-900. https://doi.org/10.4236/ce.2019.105066

Received: February 26, 2019

Accepted: May 13, 2019

Published: May 16, 2019

Copyright (c) 2019 by author(s) and Scientific Research Publishing Inc. This work is licensed under the Creative Commons Attribution International License (CC BY 4.0).

http://creativecommons.org/licenses/by/4.0/

\begin{abstract}
In the light of international goals for adult learning and lifelong learning, this paper pinpoints commonalities and differences in adult education in Norway and Spain. A critical review of international reports, national reports, and political documents indicates that ambitious and vague international intentions are difficult to implement into national educational policies. Different national challenges in the two countries make it difficult to keep up with international intentions, as they must be translated into the national societal context, including political, economic or social characteristics.
\end{abstract}

\section{Keywords}

Lifelong Learning, Adult Learning, Education Policy

\section{Introduction}

Adult education and lifelong learning are tools for tackling different national and international challenges (Griffin, 1987; Pöggeler, 1990; Milana, 2012; UNESCO, 2016). The policymaking processes at the national level are no longer independent from an international and transnational space that is instituted and sustained by nation states, international organizations, inter-state entities, and global corporations (Moutsios, 2010; Milana, 2012). Instead, these processes are blended into that space. In this transnational space, the nature and the scope of adult education are currently being revised to respond to the complexity that characterizes globalized modern societies.

International organizations such as the European Commission (EU), the Organization of Economic Co-operation and Development (OECD), and the United Nations Educational, Scientific, and Cultural Organization (UNESCO) regularly 
monitor adult education participation, political governance, education output and quality, and countries' implementation of international political strategies. These monitors indicate that across the OECD and their partner countries, the workforce has become more highly educated over the last 20 years. In 2000, most young adults had upper secondary education as their highest education level. In 2018, the largest share of 25 - 34 year olds holds a tertiary degree (UNESCO, 2016). Although more adults are reaching a higher educational level, the completion of education is still a challenge, and many adults are still left behind (OECD, 2017). Across the OECD countries that participated in the Survey of Adult Skills (OECD, 2016), about half of adults (25 - 64 year olds) participated in adult education, and most of them participated in non-formal education. For Norway and Spain, the adult education participation rates for formal or non-formal education were $65 \%$ and $47 \%$ respectively (OECD, 2017). The statistics also indicate that the percentage of adults (25 - 64 year olds) with less than upper secondary education has been falling since 2000. Across OECD countries, the share decreased from $35 \%$ in 2000 to $22 \%$ in 2016 . Seventeen percent of adults in Norway have below upper secondary school level, and 38\% have upper secondary education in 2016. By contrast, the amounts in Spain are 31\% and 23\% respectively (Education at a Glance Database). Tertiary education attainment is $48 \%$ in Norway and $40 \%$ in Spain (OECD, 2017).

Among the OECD countries, the share of total public expenditure on primary to tertiary education on all services averaged $11.3 \%$ (OECD, 2014). The corresponding share in Norway and Spain was $12 \%$ and $8 \%$ respectively. Norway has increased the expenditure by 3\% between 2010 and 2014, while Spain has lowered the expenditure by $15 \%$ within the same period (OECD, 2017).

In this paper, we will closely examine and compare the status and challenges for adult education in Norway and Spain. These are two countries that differ in location, history, government, and financial development. In the light of different social and political histories and development, we expect to find differences in the status for adult education in these two countries. The paper pinpoints updated commonalities and differences in the status for adult education and explains the differences. Through a comparative presentation that depicts the situation of adult education in the two countries, we have critically selected literature to shed light upon the situation for adult education in these countries and to define international strategies for adult learning and lifelong learning. National research, statistics, and selected political documents are used to describe adult education participation, adult education policy and challenges, and political governance. In 2008, a similar paper was written that compared Portugal, Norway, and Spain and pinpointed how historic, political, and developmental differences affected the adult education priorities in each country (Engesbak et al., 2010). As a follow-up to that paper, we now discuss the following questions: What are the similarities and differences in the status for adult education in Norway and Spain, and what are the national and regional priorities? To what extent do the countries keep up with European intentions and expectations? 


\section{A Comprehensive Strategy for Lifelong Learning}

The two main objectives of lifelong learning policy in all Europe are the development of vocational skills to enhance economic productivity, and the fostering of social inclusion and civic cohesion (Aspin \& Chapman, 2012; Holford \& Milana, 2014). Direct links are made between inclusion and economic prosperity in the "vision of a society where high skills, high rewards and access to education and training are open to everyone" (Aspin \& Chapman, 2012). In the last 15 years, one of the most interesting and surprising achievements in education and learning has been the diverse attempts for a gradual unification of lifelong learning policy in the EU. As Lima and Guimarães (2011) have stated, this is an important process that has challenged national sovereignty. "A Memorandum on Lifelong Learning" is still current, and considered the foundational document of the so-called Lisbon Strategy and primarily aims to promote a "comprehensive strategy on lifelong learning" (Commission of the European Communities, 2000: p. 6). The "Council Resolution of 27 June of 2002 on Lifelong Learning" stresses that the main goal of this policy convergence is "to achieve a comprehensive and coherent strategy for education and training" (European Commission, 2002), making lifelong learning (LLL) in Europe a reality. Lifelong learning (LLL) is defined as follows:

All learning activity undertaken throughout life, with the aim of improving knowledge, skills and competences within a personal, civic, social and/or employment-related perspective (Commission of the European Communities, 2001: p. 9).

The memorandum differentiates three types of learning: formal, non-formal, and informal learning (Commission of the European Communities, 2007: p. 8). The memorandum also states the main aims for this common policy on LLL through six key messages, all of which stress the importance of LLL (Commission of the European Communities, 2000: pp. 10-20). These messages are meant to edify a "knowledge-based economy and society" (Commission of the European Communities, 2000: p. 3) that would transform Europe into the most competitive and dynamic knowledge-based society in the world by 2010 (Commission of the European Communities, 2007: p. 2). The key message, "New skills for all", aims to "Guarantee universal and continuing access to learning for gaining and renewing the skills needed for sustained participation in the knowledge society" (Commission of the European Communities, 2000: p. 10). These basic skills for sustained participation include IT skills, foreign languages, technological culture, entrepreneurship, and social skills. One of the goals of these basic skills is as follows:

To encourage and equip people to participate more actively once more in all spheres of modern public life, especially in social and political life at all levels of the community, including at European level (Commission of the European Communities, 2000: p. 4, bold type in the original).

Basic skills are always associated with two different domains: active citizen- 
ship and employability. As active citizenship is not presented as an objective in and of itself, an important dual discourse arises, distinguishing concept from practice. This dual discourse specifically concerns LLL practices, with the stronger discourse focusing on the labour market rather than citizens' rights and participation. Policymakers seem to have forgotten that education and learning should span an entire lifetime, rather than using education just for job preparation and defining it by competitiveness. This is evident in the 2007 document "It is always a good time to learn", where the practices become the dominant discourse. "The Action Plan on Adult Learning" (Commission of the European Communities, 2006) focuses on responding to the following challenges: competitiveness, demographic change, and social inclusion. Responses to the last challenge, social inclusion, are meant to eliminate poverty among marginalized groups.

We think that the most powerful and important critique that can be made concerning current policies and practices on LLL is that the aims of education should be for education's own sake. According to Dewey ([1916] 1995), the most important achievement in a democratic society is the role of education in encouraging personal and collective development. However, LLL's policies subordinate these educational aims into professionalization and business. As Dewey has also stated, in a democratic society, learning and teaching cannot become mere resources to achieve aims disconnected from the educational means. Finally, as Gelpi has stated, adult education in Europe seems to have progressively forgotten its history made of fighting, resistances, and creativity and is transforming into an instrument of power only used for personal development and following the logic of the market (Gelpi, 2004: p. 153).

To better understand the relationship between international and national lifelong learning policies, this study draws on two different perspectives. Sociological institutionalism accounts for the similarity in principles and values that influence lifelong policy development across countries (Meyer, Boli, Thomas, \& Ramirez, 1997), with the intention of gradual unification. International forces such as international economic forces; social trends; and national factors such as policy, culture, economy, and development highly influence the situation for national adult education (ECON, 2008). From this perspective, the nation state's policies are significantly affected by the relative positioning of adult education and learning on the policy agenda of major transnational organizations and inter-state entities.

A second perspective is a socio-contextual model that highlights societal context to explain the formation and implementation of policy (Westheimer \& Kahne, 2004). From this perspective, the status for adult learning will differ among countries because the definitions and purposes of adult education are culture-specific and are based on its social, political, and economic needs. National intentions, investments, efforts, and focus will vary as every nation has its own problems that adult education can help to repair. Education is understood 
within broad contextual factors such as political, economic, or social characteristics which vary from one society to another (Bennett, 1991).

\section{The Situation for Adult Education in Norway}

Formal education includes all officially approved education that leads to formal competence. Non-formal education includes courses, seminars, and conferences where education is the main purpose of participation, as well as private lessons and lectures that are not included in formal education. In addition, non-formal education includes scheduled periods of organized guidance in the work situation of a colleague, instructor, or supervisor. This is known as "guided on-the-job training". Informal learning is knowledge acquired by adults apart from organized education and training programs (Illeris, 2012). One main characteristic of the research on adult learning, both Norwegian and international, is that it has focused separately on the different forms of learning (informal, formal, and non-formal), without emphasizing the relationship between them (Stenøien \& Tønseth, 2017).

In Norway, adult participation in formal and non-formal learning has been relatively stable between 2012 and 2017. In 2017, 60\% of all adults between 25 and 64 years of age have participated in formal or non-formal learning. The participation percentage is equal between men and women. As is expected, the participation rate is highest for those who had the highest level of education (76\%) and lowest for those who had the lowest level of education (40\%) (Statistics Norway, 2017a).

In a labour market undergoing rapid change, employees experience stricter requirements for work-related competence. The workplace is an important arena for non-formal education in Norway. In 2017, more than half of the adult population were participating in non-formal education (Statistics Norway, 2017c).

The public sector is one of many providers of adult education in Norway, which offers formal learning at different educational levels. Study associations, voluntary organizations, online schools, and private providers offer formal education as well as informal learning. In 2016, there were 505,000 participants in 45,000 eligible courses arranged by the study associations. Of all participants, $28 \%$ were in the age group 14 - 29 years, $29 \%$ were in the age group 30 - 49 years, and $43 \%$ were 50 years and older. Like all previous years, female participants were the majority. Women accounted for $57 \%$ of all participants in 2016 (Statistics Norway, 2017a).

\subsection{Lack of Labour and Competence}

Norwegian employers are in desperate need of people to fill certain positions within many occupations. At the same time, more than 138,000 people are unemployed (4.8\% relative to the workforce in the third quarter of 2016) (Statistics Norway, 2017c). The problem is often that the job seekers' knowledge and com- 
petence do not match the needs of the employer.

In addition to a labour market in constant conversion, expectations of labour shortages in the years to come are linked to demographic trends. The population is increasing and lives longer than before. This means that there will be more retirees and fewer professionals. High occupational activity among people of working age is important for ensuring welfare and value creation. In this context, it is a challenge that many workers leave work before the normal retirement age for various reasons. It is also a major challenge that many people are outside of working life for different reasons (Tønseth, 2011).

Validation is one measure that aims to highlight and confirm a person's competency, so that the person can move on to employment or education. Validation allows foreign-born citizens to be credited with the formal and informal skills they bring from their home countries. The Directorate of Education has established national guidelines for the implementation of competence assessments in Norway to ease the validation process (Tønseth, 2011).

\subsection{Social Equality and Inclusion}

The overall objective of education policy in Norway is to create a knowledge-based society with strong solidarity and provide enough education opportunities for all (Ministry of Education and Research, 2009, 2016). Equality is the essential value in the Norwegian welfare state. The central goals for adult learning are value creation, competence raising, inclusion in social life and working life, the individual ability to cope in everyday life, cultural development, and the provision of a safe platform for life (Ministry of Education and Research, 2009, 2016).

There is an assumption that inclusionary practice will be created through adult education and learning (The Norwegian Government, 2017). In Norway, the focus has been on arranging study opportunities for groups that do not usually participate in lifelong learning. Adults that are outside of working life and education must have the opportunity to compensate for their lack of the skills necessary to gain employment. These groups are the long-term unemployed, immigrants, and other people dependent on social security (The Norwegian Government, 2017). The goal is to make educable people employable. This is in accordance with the OECD Skills Strategy (OECD, 2014).

In the National Policy Strategy on Competence 2017-2021, voluntary organizations are featured as an important learning arena with which many adults in Norway are affiliated. The strategy underlines that organizations, including study associations, offer a wide range of courses and education opportunities. Some courses directly target specific competences demanded in working life, while others contribute to building basic competences such as language, the ability to cooperate, the development of social skills, personal development, and the ability to learn.

Immigration and inclusion were recently highlighted in the Norwegian official 
report "Integration and trust. Long-term consequences of high immigration" (NOU 2017:2). According to this report, the Norwegian integration regime has gradually moved from a policy of securing basic rights to a focus on work-promoting measures. By the beginning of 2017, Norway had 725,000 resident immigrants, which represented $13.8 \%$ of the entire population. This is primarily due to labour immigration from the EU's new member states from Eastern Europe and the many refugees who have found their way to Norway (Statistics Norway, 2017a). In 2016, over 31,000 immigrants found their way to Norway, mostly from Syria, Afghanistan, and Iraq. Not all asylum seekers could stay in Norway (Gravdahl \& Wilskow, 2016). As time goes by, family immigration from the countries where refugees come from is expected because refugees usually stay in Norway and seek to bring their family later (Dzamarija \& Sandnes, 2016). The main strategy for the integration policy in Norway is to promote basic skills such as social basic skills (capacity to communicate, think critically and creatively, and develop self-criticism). In addition, the focus is placed on opportunities for continuing education and personal development; and inculcates knowledge, creativity, and the aptitude to learn new things and handle change, so that people can have better chances at finding employment.

The common understanding is that employment for as many as possible is necessary to uphold the welfare state (Midtbøen \& Rogstad, 2012). However, immigrants face difficulties in accessing the labour market. Even highly skilled immigrants have a lower employment rate than average. This means that many immigrants experience a reverse class journey in their new country (Fossland \& Aure, 2011). Lack of occupational participation is not just about individual characteristics and qualifications; it must also be viewed in connection with the features of public agencies and employers' attitudes towards recruiting immigrants (Sandbæk \& Djuve, 2012; Midtbøen \& Rogstad, 2012).

When we write about immigrants and Norwegians born to immigrant parents, it is important to remember that there are hardly any other groups as heterogeneous and complex. At the beginning of 2017, Norway contained people with backgrounds from a total of 221 countries and autonomous regions in Norway (Statistics Norway, 2017b).

The Norwegian Labour and Welfare Administration (NAV) is the Norwegian public welfare agency. The agency consists of the state Labour and Welfare Service as well as municipal welfare agencies. It is responsible for a third of the state budget of Norway and administers programs such as unemployment benefits, pensions, child benefits, and more. The NAV subsidizes education and learning and supports unemployed people to find employment. The agency offers counselling services and different courses that aim to increase the possibility of finding employment.

\subsection{Innovation and Economic Growth}

Innovation is the driver of long-term economic growth (Metcalfe, 1998; Fager- 
berg, 2003). The national and international economy is increasingly knowledge-driven (Dicken, 2011), and new knowledge, or dissemination of existing knowledge, are crucial to innovation (Maskell \& Malmberg, 1999). Learning, learning processes, and new knowledge are viewed as key elements for innovation. For companies and organizations, it is crucial to connect knowledge and resources in new ways. There are various forms of knowledge that are important in relation to innovation and economic growth, the competition for image is more complex than before, and production processes and markets are increasingly complex and insightful. The struggle for knowledge and creativity is increasing and has become global (Malecki, 2010). In Norway, the degree of formalized education and knowledge development is regarded to be crucial to economic development. The global economy is changing rapidly, and in order to maintain existing levels of competition and value creation, Norwegian companies and regions must compete on new terms. Knowledge is a key factor in this competition. The decisive factor is also how companies are organized or structured, what innovation strategies and management culture they have, and how these strategies and culture facilitate the formal and informal flow of knowledge in organizations and businesses (Nonaka \& Takeuchi, 1995). This is currently a challenge for many companies in Norway.

Compared with other countries, Norway has high participation in LLL and scores highly in terms of the proportion of learning-intensive work. Despite this, Norway scores below the average in international research on innovation. In 2011, Nordic Institute for Studies in Innovation, Research and Education (NIFU) conducted a survey of knowledge status regarding competence and innovation and concluded that there is a need for more knowledge about what kind of competence can contribute to increased innovation. In this context, there is also a need to draw attention to how employers and companies apply the available expertise (Thune, Olsen, \& Solberg, 2011).

\subsection{Responsibility for Adult Learning in Norway}

The distribution of responsibilities regarding adult education and learning takes place across three different levels. The Ministry of Education and Research is responsible for primary school, secondary school, upper secondary and tertiary vocational education, higher education sectors, kindergartens, cultural schools, vocational education and training, and adult learning. The Ministry of Education and Research is also responsible for the general regulatory framework, national strategies, and laws concerning adult education. The Norwegian Directorate for Education and Training represents the central government at the regional level. In cooperation with municipal and county authorities, the National Education Office ensures that appropriate schooling is provided for young people in compliance with all the relevant regulations. It also ensures the provision of adequate adult education facilities. The County Council is responsible for all education in upper secondary school, and each municipality is responsible for primary school and introductory programs for new immigrants in Norway (Ut- 
danningsdirektoratet, 2011).

\subsection{Weakness and Strength-Adult Education and Learning in Norway}

The general level of competence is high in Norway but concerns about adults' basic skills have contributed to a profound commitment to this issue (OECD, 2014). Equal opportunities are a deeply rooted value in Norway, which contributes to the constant increase of incentives to protect marginalized groups and include them into education, learning, and work. However, it has not been proven by research that equal access leads to increased participation (Tønseth, 2011). However, it has been pointed out that the overview of learning efforts and a statistical basis for adult learning must be improved (OECD, 2014). All levels from adult education centers, schools, municipalities, and county municipalities must have data entry that is correct and coordinated. It is very difficult to obtain a full overview of initiatives, practices, and actors. There is also a lack of coordination between the various actors responsible for adult education and learning. It is necessary to have better management, coordination, and competence among the teachers who teach adults.

\section{The Situation for Adult Education in Spain}

The specific objectives of adult education in Spain is about updating the educational qualifications, to develop programs and courses related to specific educational needs from excluded groups as well as to develop people's capacity to participate in social, cultural and political events (Ministerio de Educación, 2006). These objectives are in line with the European lifelong learning policy. Education authorities are the main providers of formal adult education in basic skills. There are around 1407 public adult education institutions, 147 adult education classrooms, 280 secondary schools where adults can obtain a degree in compulsory secondary education, and 32 institutions related to distance adult education. Adult education for prisoners is one example of the latter. Distance learning and classroom-based provision by education authorities include basic and compulsory education or professional training. There are also some programs provided in a university setting, such as the Universities of Third Age or The Experience Classrooms, which are specifically targeted at older adults (Valle, 2014).

Specifically, the offer to help adults to improve their basic skills includes the following levels of education: Basic education for adults divided into initial education and secondary education. The first is also divided in two different levels. Level 1, or literacy that aims to provide people with literacy and numeracy skills, and Level 2, or consolidation of knowledge and instrumental techniques that aim to enable adults to participate in social, cultural, political, and economic life.

Secondary education for adults is organized in three areas: communication, including a foreign language; social sciences, geography, history, and citizenship 
education; and the scientific-technological area that includes mathematics, technology, health and the environment. Vocational secondary education for adults involves 2 years of training and is classroom-based in adult education schools. Finally, language education is also provided to acquire the basic user level (A1 and A2) according to the Common European Framework of Reference for Languages. These types of provision lead to obtaining a certificate.

There are also private institutions. During the 2014/2015 academic year, there were 99 private adult education institutions, which represented $4.51 \%$ of the offerings. These falls into three main categories: not-for-profit institutions, including popular universities; private for-profit institutions usually related to language and professional training; and private for-profit institutions that focus on the provision of distant learning. Usually, not-for-profit institutions are financed from public budget. Only some schools of business and schools of language can be considered to be self-financing private institutions (Ministerio de Educación, 2006).

\subsection{Tools for Obtaining a Recognized Qualification}

Adults can achieve a recognized qualification from education authorities after finishing the types of study presented in the previous section or by finishing the Bachillerato (post-secondary education, which is compulsory) or vocational training for adults. This official qualification provides the development and consolidation of basic skills and enables adults to access vocational training, artistic education, and university education.

The major providers in this domain are local authorities and civil society organizations that organize a wide range of cultural activities. The Popular Universities are one example (Federación Española de Universidades Populares, 2018). The Popular Universities organize official studies and cultural activities such as leisure workshops, activities related to local history and traditions, and visits to historical places. Local authorities also offer an assorted array of cultural activities through community centers.

The Ministry of Employment and Social Security is the main provider of training that helps unemployed people or those at risk of unemployment to transition to the labour market. This includes supplying training for people with special training needs or those who face difficulties in accessing the labour market. The Department of Employment and Social Security develops an annual program that considers proposals made by the autonomous communities. This program includes the following: subsidizing training actions with a recruitment commitment for least $60 \%$ of the trainees; training plans to help the unemployed access existing employment opportunities; and training programs for specific groups, especially young people (EAEA, 2011).

Finally, it is important to stress the Plan PREPARA for people who cannot access unemployment benefits. These people are encouraged to take part in training that helps them to obtain a new qualification or reintegrate into the la- 
bour market. In addition, participants are also provided with financial support for 6 months while training. This plan was agreed on between the state and the autonomous communities.

There are three routes to higher education for adults, which have unique entry requirements (for non-traditional applicants): one route for people over 25; another route that is related to professional experience for those over 40; and another route for people over 45. Another way that adults can also access adult education is through the universities of the third age. Usually, these universities of the Third Age-otherwise known as Experience Classroom (Aula de la Experiencia, in Spanish) as run by the University of Seville, for instance, organize more leisure activities than degree study programs (Universidad D Sevilla, 2018).

Another path is related to taking a master's degree program either at public or private universities or in other institutions such as the chambers of commerce. Currently, master's degrees are considered to be important qualifications that enable people to access the labour market or improve internal prospects in companies.

There are several programs related to specific groups such as migrants. These are mainly developed by civil society organizations that focus on teaching Spanish and other co-official languages as a second language. Other programs are specially geared towards Gipsy people.

\subsection{Responsibilities Regarding Adult Education in Spain}

The distribution of responsibilities regarding adult education and learning takes place across three different levels. The first is the state level. The Ministry of Education is responsible for the general regulatory framework. The most recent legislative measures have involved a shift in some regulatory powers to a more centralized organization. The second level involves departments of education or the equivalent in the different autonomous governments that are responsible for implementing specific policies on adult education and learning. The third level is the local authority in municipalities that are responsible for the maintenance of buildings. They also organize some training that is mostly related to leisure activities: dance, painting, sewing, sports, and so on. The provision of employment-related training is regulated by the Department of Employment and Social Security through the State Public Employment Service (SEPE). However, these activities are also organized in the same framework that was discussed in the previous paragraph. Specifically, the SEPE is only in charge of training provision when it goes beyond the territorial scope of an autonomous community or in areas where the state maintains full competences (the army, prisoners, etc.)

The autonomous governments are responsible for the implementation of these training initiatives in the framework of state regulations. For instance, the Autonomous Government of Andalusia announced the restart of training actions for the unemployed that were suspended in 2011. In the case of Seville, this 
involved spending approximately EUR 15 million to organize 419 training actions for 6,285 unemployed people.

Local authorities such as municipalities and supra local entities called diputaciones, business organizations, trade unions, or accredited training companies collaborate to implementing these training programs. For instance, the Diputación of Seville organizes an employment program for young people. Around EUR 3.3 million from the European Social Fund has been invested in this programme (EAEA, 2011).

\subsection{Adult Education in Spain, Some Weakness and Strengths}

Adult education and learning in Spain has some weakness and strengths. The first weakness is related to the lack of a strong culture of learning in the country. This can be related to relatively low levels of literacy. Based on figures from the census of 2011, just under a third (31\%) of the adult population in Spain is functionally illiterate (EAEA, 2011). Other figures indicate that $43 \%$ of adults have a low level of education. Other data on the behavior of the population are useful: figures from 2014 indicate that only 33\% of the population visited a museum, $62 \%$ read a book, and 23\% attended theatre performances (EAEA, 2011).

On the other hand, there is a lack of training focused on specific teaching approaches for adults. The psychology of the adult and specific teaching methodologies used in adult learning are not seen as important elements of teacher training in most faculties of education (Guimaraes et al., 2018).

Finally, there is a lack of political consensus about the fundamental building blocks of the educational system in Spain (Guimaraes et al., 2018). Because the education system is a partisan battlefield, new governments tend to introduce new educational laws that lead to disruption and a lack of stability during practical implementation. This lack of consensus is regarded as the reason for the relatively poor performance of the educational system in Spain; the proportion of early school leavers in 2015 is currently around 20\% (23.2\% were men and $15.4 \%$ were women). There are also significant variations in the education system across the different territories in Spain. For instance, the rates of early school leavers in 2015 were 24.9\% in Andalusia, 18.8\% in Catalonia, and 24.5\% in Extremadura, a poor region. However, the rate was $10.8 \%$ in Navarra, one of the richest regions in Spain (Guimaraes et al., 2018).

It can be argued that adult education in Spain has traditionally been linked to communities, either socially or economically (Guimaraes et al., 2018). While a part of this important tradition has been lost, its influence remains, as seen in the communities of learning that operate in disadvantaged neighborhoods such as the Polígono Sur (South District) in the city of Seville and other similar initiatives spread around the country. These kinds of initiatives can be considered strengths because they motivate people to participate in learning activities. Additionally, La Verneda is an adult education school in Barcelona that is an example of a community of learning.

It is important to mention the role of civil society organizations in filling gaps 
in adult education and the provision of learning. For example, in the city of Seville, Hermandades (Fraternities) is conducting important work on literacy for migrants. This also occurs in other countries in Europe. Another example is El Vacie, a shanty dwelling neighborhood in Seville, where volunteers of civil society organizations help people deal with issues such as child care, health and, personal and family hygiene. These programs are effective practices. For instance, the programs in El Vacie have improved family hygiene and other health issues.

\section{Discussion}

The main objectives of the European lifelong learning policy focusing on developing vocational skills and fostering social inclusion and civic cohesion (Aspin \& Chapman, 2012), have influenced adult education policy, both in Norway and Spain. One can say that the Lisbon strategy that aims to promote a "comprehensive strategy on lifelong learning" is in line with sociological institutionalism. This theory accounts for the similarity in principles and values that influence lifelong policy development across nations (Meyer, Boli, Thomas, \& Ramirez, 1997). An international strategy on LLL was meant to edify a "knowledge-based economy and society" (Commission of the European Communities, 2000: p. 3) for transforming Europe into "the most competitive and dynamic knowledge-based society in the world by 2010" (Commission of the European Communities, 2007: p. 2). In promoting the strategy, policymakers focused on education as a means of job preparation as defined by competitiveness. In doing so, they overlooked both the life-wide and lifelong dimensions of education. The importance of active citizenship, equality, and good lives for all people as interrelated aims for lifelong learning were not sufficiently communicated (Commission of the European Communities, 2000: p. 4).

Unilateral, ambitious, and vague intentions are difficult to implement into every nation's educational policies (Walters \& Watters, 2017). International aims must be translated into national standards and the societal context (Westheimer \& Kahne, 2004). From this perspective, the status for adult learning will differ among countries, because the definitions and purposes of adult education are culture-specific and based on the country's social, political, and economic needs.

Apparently, Norway has considered the economics-based international comprehensive strategy on LLL. Norway has achieved impressive levels of socio-economic development with stable and inclusive economic growth that builds on a highly qualified population, a high employment rate, skilled labour immigration, and high productivity. Everyone in Norway has the statutory right and opportunity to obtain 13 years of education, and university and college studies are open to anyone. Norway also has prudent management of its petroleum profits and an inclusive welfare state. Even so, Norway faces slowing productivity growth in the mainland economy, high real labour costs, and an underuse of skills for entrepreneurship and innovation. In addition, Norway faces declining oil production 
and the consequent adjustment to a non-oil economy.

In addition, the refugee crises in Europe have highlighted debates over the role of adult learning and the best way for rapid inclusion into society and working life. In Norway, more attention is placed on the importance of informal learning and qualifications that encompass different competencies. Innovation is also prized because Norway has long traditions of incorporating culture and learning into workplace practices. In summary, there are three main challenges that Norway faces in emphasizing education as key tools. The first 1) is the lack of labour and competence, the second is 2) social equalization and inclusion, and the third 3) is the need for innovation and economic growth. These challenges are the social context that has set the agenda for adult learning strategies in Norway. Norway seems to follow international strategies, but national challenges make that task slightly difficult. In Norway, the importance of voluntary sector in adult education has declined for the last 15-20 years. In many ways, the voluntary sector has existed separately from the official Norwegian educational policy, which is a pity because they organize many different learning activities, both formal and non-formal (Stenøien \& Tønseth, 2017).

Developing a uniform overview of Spain's adult learning system is very difficult. These difficulties have intensified because of the tensions between the central and autonomous governments who are competing for control on issues of funding and the enacting laws, which have been ongoing while this article was being prepared. These tensions have led to uncertainty in the system. Some policy elements are in the hands of the autonomous governments such as health services, public transportation, taxes, and education. Every territory has full legislative authority and considers the minimum standards set up by the national government's Ministry of Education, Culture, and Sports.

In terms of adult education, there is no adult education law that exists at the national level. However, there are adult education laws in Galicia (1992), Valencia (1995), the Canary Islands (2003), and the Balearic Islands (2006). There is also the Organic Education Act (2006) which was followed by an Education Act (2007) in Andalusia, and another Education Act (2009) in Catalonia. Other ministries are also involved in adult education and learning, including the Ministry of Employment and Social Security. Each territory in the state therefore has full legislative power and can implement its own legislative measures pertaining to adult education in the framework of the minimum standards set by the state ministry.

Regarding administrative terms, the set-up of each department in every territory can be different and can change when the "color" of the autonomous government in a territory changes. In this context, it is very difficult to define a lifelong learning strategy that can be implemented at a national level. However, it is possible to identify and define the main legal documents that regulate adult education at a national level. Finally, it is important to stress that education has been-and still is-a partisan issue. This means that each turn of government-from left to 
right, or vice versa-means new regulations. The former Ministry of Education in the last socialist cabinet tried to implement an agreement related to education that consisted of 148 measures. The agreement failed because education has become a partisan issue. Presently in 2018, there is an ongoing attempt to sign a new agreement that has tried to remove education from the partisan debate. However, this has presented some difficulties.

Based on the context for developing policy in Spain as set out above, it can be concluded that while there is a lifelong learning strategy at the national level, this is subject to specific and practical interpretation at the territorial level. Another way of explaining adult education policy is that there are similar practices across the country, but developments and practices vary across regions.

The meaning of adult learning is defined in central political documents in Europe, and globalization and international competition make the introduction of standards relevant for certain competences. If European intentions and goals are to be followed, nations may feel pressed to keep up with those standards.

Common features between Norway and Spain include the focus on basic skills, dropouts, inclusion, and a lack of teacher competence in adult education. In addition, the status of adult learning in both countries implies the importance of the volunteer sector and volunteer organizations. Such organizations safeguard the softer values in adult learning such that active citizenship, inclusion, equality, and well-being are important elements in both countries. In both countries, the status of adult education is linked to three circumstances:

1) The management and degree of control of the national government.

2) The voluntary efforts and contributions from the voluntary sector are the cornerstone of the development of adult education in Norway and Spain.

3) In both countries, the role of adult education is closely related to main characteristics of development that have come to pass in the countries and regions. In Spain, these characteristics are illiteracy as well as different foci and governance in different regions. In Norway, these characteristics are immigration and inclusion efforts. Both countries focus on basic skills. Both in Norway and Spain, there has been rapid development in adult learning, and raise the following question about what has been missed along the way: what about local development, voluntary education, and individual growth?

\section{Conclusion}

According to sociological institutionalism, European lifelong learning policy is not adopted solely because it is considered the most rational, but because they are part of a set of adopted international rules that are considered appropriate and accepted by European organizations promoting lifelong learning policy. It seems to be a mutually constitutive character in balancing between a national strategy tightly bounded up to national challenges and ways of recognizing lifelong learning policy and respond to the European strategy. As a conclusion, both sociological institutionalism and socio-contextual elements are included in both 
nations' focus and strategies in terms of the national and regional adult education policy. Both nations have national and local priorities. Their national preferences and challenges related to history, developmental speed, mode of living, and traditions are strong incorporated structures that meet European standards, competitiveness, and economic growth. Education is understood within broad contextual factors such as political, economic, or social characteristics which vary from one society to another (Engesbak, Tønseth, Fragoso, \& Lucio-Villegas, 2010; Holford \& Milana, 2014).

There are also different philosophical and political assumptions about the practice of adult education because nations and governments rely on different governance perspectives and strategies. An adult education policy that is globally applicable is therefore difficult to achieve (Engesbak et al., 2010; Holford \& Milana, 2014), despite each country having an influence on international political strategies for adult education and lifelong learning because they are members of different international organizations.

Sociological institutionalism accounts for the similarity in principles and values that influence lifelong policy development across nations (Meyer, Boli, Thomas, \& Ramirez, 1997). International forces such as international economic forces; social trends; and national factors such as policy, culture, economy, and development significantly influence national adult education (ECON, 2008).

International strategy must consider that countries are different and that countries that are governed differently have different national challenges and allocation structures. These differences can make it difficult to meet international strategies, but the differences reveal values within adult learning that are adapted to national challenges. Individual well-being and increased participation in different areas of society are more closely related to national interests in Norway and Spain. Even so, all macro perspectives in adult education must necessarily be related to individuals and their choices and actions (Tønseth, 2011).

\section{Conflicts of Interest}

The authors declare no conflicts of interest regarding the publication of this paper.

\section{References}

Aspin, D. N., \& Chapman, J. D. (2012). Towards a Philosophy of Lifelong Learning. In D. N. Aspin, J. Chapman, K. Evans, \& R. Bagnall (Eds.), Second International Handbook of Lifelong Learning (pp. 3-35). Dordrecht: Springer Netherlands. https://doi.org/10.1007/978-94-007-2360-3_1

Bennett, R. E. (1991). On the Meanings of Constructed Response. ETS Research Report Series, No. 2, 1-46. https://doi.org/10.1002/j.2333-8504.1991.tb01429.x

Commission of the European Communities (2000). Commission Staff Working Paper: A Memorandum on Lifelong Learning. Brussels: European Union. http://arhiv.acs.si/dokumenti/Memorandum_on_Lifelong_Learning.pdf

Commission of the European Communities (2001). Communication from the Commis- 
sion: Making a European Area of Lifelong Learning a Reality. Luxembourg: Publications Office.

Commission of the European Communities (2006). Communication from the Commission-Adult Learning: It Is Never Too Late to Learn. Report, Brussels.

Commission of the European Communities (2007). Council Resolution of 15 November 2007 on Education and Training as a Key Driver of the Lisbon Strategy. Official Journal of the European Union, C300, 1-2.

https://eur-lex.europa.eu/legal-content/EN/TXT/PDF/?uri=CELEX:32007G1212(01)\&f $\underline{\text { rom }=\mathrm{EN}}$

Dewey, J. [1916] (1995). Democracy and Education: An Introduction to the Philosophy of Education. New York: Macmillan.

Dicken, P. (2011). Global Shift: Mapping the Changing Contours of the World Economy (6th ed.). London: Sage.

Dzamarija, M. T. \& Sandnes, T. (2016). Familieinnvandring og ekteskapsmønster 1990-2015 [Family Immigration and Marriage Pattern 1990-2015]. Report 2016/39, Oslo: Statistisk Sentralbyrå.

EAEA (2011). Country Report on Adult Education in Spain. https://eaea.org/country/spain/

ECON (2008). Adult Training. What Can We Learn from Europe. Commissioned by the Norwegian Ministry of Education and Research. ECON-Report 2008-117.

Engesbak, H., Tønseth, C., Fragoso, A., \& Lucio-Villegas, E. (2010). Adult Education in Transition: Three Cases and Periods Compared. International Journal of Lifelong Education, 29, 617-636. https://doi.org/10.1080/02601370.2010.512811

European Commission (2002). Council Resolution of 27 June 2002 on Lifelong learning. Official Journal of the European Union, C163, 0001-0003.

https://eur-lex.europa.eu/legal-content/EN/TXT/PDF/?uri=CELEX:32002G0709(01)\&f rom $=\mathrm{EN}$

Fagerberg, J. (2003). Schumpeter and the Revival of Evolutionary Economics: An Appraisal of the Literature. Journal of Evolutionary Economics, 13, 125-159.

https://doi.org/10.1007/s00191-003-0144-1

Federación Española de Universidades Populares (2018). FEUP. http://www.feup.org/category/eventos-nacionales/

Fossland, T., \& Aure, M. (2011). When Higher Education Is Not Enough: Integration of Highly Educated Immigrants in the Labour Market. Sosiologisk Tidsskrift, 19, 131-152.

Gelpi, E. (2004). Trabajo Futuro: La formación como proyecto político. Xâtiva: Edicions del CREC.

Gravdahl, B., \& Wilskow, R. (2016). UDI og utlendingsforvaltningen [UDI and Immigration Administration]. Samfunnsspeilet, 4.

Griffin, C. (1987). Adult Education as Social Policy. London: Croom Helm.

Guimaraes, P., Lucio-Villegas, E., \& Mayo, P. (2018). Southern-European Signposts for Critical Popular Adult Education: Italy, Portugal and Spain. Compare: A Journal of Comparative and International Education, 48, 56-74.

https://doi.org/10.1080/03057925.2017.1283584

Holford, J., \& Milana, M. (2014). Introduction: European Adult Education Policy in Question. In M. Milana (Ed.), Adult Education Policy and the European Union: Theoretical and Methodological Perspectives. Research on the Education and Learning for Adults (pp. 1-12). Rotterdam: Sense Publishers.

Illeris, K. (2012). Læring [Learning]. Oslo: Gyldendal Akademisk. 
Lima, L. C., \& Guimarães, P. (2011). European Strategies in Lifelong Learning: A Critical Introduction. Opladen and Farmington Hills: Barbara Budrich Publishers. https://doi.org/10.3224/86649444

Malecki, E. J. (2010). Global Knowledge and Creativity: New Challenges for Firms and Regions. Regional Studies, 44, 1033-1052. https://doi.org/10.1080/00343400903108676

Maskell, P., \& Malmberg, A. (1999). The Competitiveness of Firms and Regions: "Ubiquitification" and the Importance of Localized Learning. European Urban and Regional Studies, 6, 9-25. https://doi.org/10.1177/096977649900600102

Metcalfe, J. S. (1998). Evolutionary Economics and Creative Destruction. London: Routledge.

Meyer, J. W., Boli, J., Thomas, G., \& Ramirez, F. O. (1997). World Society and the Nation-State. American Journal of Sociology, 103, 144-181. https://doi.org/10.1086/231174

Midtbøen, A. H., \& Rogstad, J. (2012). Diskrimineringens omfang og årsaker. Etniske minoriteters tilgang til norsk arbeidsliv [Scope and Causes of Discrimination. Ethnic Minorities Access to Norwegian Working Life]. Rapport 1/12. Oslo: Institutt for Samfunnsforskning.

Milana, M. (2012). Globalisation, Transnational Policies and Adult Education. International Review of Education, 58, 777-797. https://doi.org/10.1007/s11159-012-9313-5

Ministerio de Educación (2006).

Ministry of Education and Research (2009). Adult Education Act. https://lovdata.no/dokument/NL/lov/2009-06-19-95

Ministry of Education and Research (2016). Report No. 16 to the Storting (2015-2016). Fra utenforskap til ny sjanse. Samordnet innsats for voksnes læring https://www.regjeringen.no/no/dokumenter/meld.-st.-16-20152016/id2476199

Moutsios, S. (2010). International Organisations and Transnational Education Policy. Compare: A Journal of Comparative and International Education, 39, 469-481. https://doi.org/10.1080/03057920802156500

Nonaka, I., \& Takeuchi, H. (1996). The Knowledge-Creating Company: How Japanese Companies Create the Dynamics of Innovation. Long Range Planning, 29, 592. https://doi.org/10.1016/0024-6301(96)81509-3

NOU (Official Norwegian Reports) 2017:2 (2017). Integrasjon og tillit-Langsiktige konsekvenser av høy innvandring [Integration and Trust]. https://www.regjeringen.no/en/dokumenter/nou-2017-2/id2536701/

OECD (2014). Skills Strategy. Action Report Norway. https://www.kompetansenorge.no/statistikk-og-analyse/publikasjoner/oecd-skillsstrate gy-action-report-norway/

OECD (2016). The Survey of Adult Skills: Reader's Companion (2nd ed.). Paris: OECD Publishing. https://doi.org/10.1787/9789264258075-en

OECD (2017). Education at a Glance 2017: OECD Indicators. Paris: OECD Publishing.

Pöggeler, F. (Ed.) (1990). The State and Adult Education. Frankfurt am Main: Verlag Peter Lang.

Sandbæk, M. L., \& Djuve, A. B. (2012). Fortellinger om motivasjon. Hva er gode arbeidsmetder i NAVs AMO-kurs for innvandrere? [Stories about Motivation]. Fafo-Report 2012:27. Oslo: Fafo.

Statistics Norway (2017a). Adult Learning. https://www.ssb.no/utdanning/statistikker/vol

Statistics Norway (2017b). Innvandrere og norskfødte med innvandrerforeldre, 1. Januar 
2017: Flest nye bosatte fra Syria [Immigrants and Norwegians with Immigrant Parents]. https://www.ssb.no/befolkning/statistikker/innvbef/aar

Statistics Norway (2017c). Dette er Norge 2017. Tall Som Forteller. Report. http://www.ssb.no/befolkning/artikler-og-publikasjoner/dette-er-norge-2017

Stenøien, J. M., \& Tønseth, C. (2017). "Possibility-Rooms” for Learning and Inclusion. Adult Education in the Age of Global Mobility. Paper to the 7th Nordic Conference on Adult Education and Learning, 3-5 May 2017.

The Norwegian Government (2017). Satsing på voksnes læring [Commitment to Adult Learning].

Thune, T., Olsen, D. S., \& Solberg, E. (2011). Kompetanse for innovasjon: En oversikt over forskningslitteratur, policy og virkemidler [Competence for Innovation: An Overview of Research, Policy and Means]. Rapport No. 36, Oslo: Nordisk institutt for studier av innovasjon, forskning og utdanning.

Tønseth, C. (2011). Voksne i læring. Identitetskonstruksjon i lys av Kompetansereformen [Adults Participating in Learning Activities. Identity-Construction in the Light of the Norwegian Competence Reform]. Ph.D. Dissertation, Trondheim: Department of Sociology and Political Science, Norwegian University of Science and Technology.

UNESCO (2016). Background Paper Prepared for the 2016 Global Education Monitoring Report. Education for People and Planet: Creating Sustainable Futures for All.

Universidad D Sevilla (2018). Studies and Access. http://www.us.es/

Utdanningsdirektoratet (2011). OECD Review on Evaluation and Assessment Frameworks for Improving School Outcomes: Country Background Report for Norway. http://www.oecd.org/dataoecd/7/10/47088605.pdf

Valle, J. E. (2014). Educación permanente: Los programas universitarios para mayores en España como respuesta a una nueva realidad social. Revista de la Educación Superior, 43, 117-138. https://doi.org/10.1016/j.resu.2015.03.003

Walters, S., \& Watters, K. (2017). Reflecting on the Global Report on Adult Learning and Education in the "Post-Truth Society". Adult Education Quarterly, 67, 228-237. https://doi.org/10.1177/0741713617700675

Westheimer, J., \& Kahne, J. (2004). What Kind of Citizen? The Politics of Educating for Democracy. American Educational Research Journal, 41, 237-269.

https://doi.org/10.3102/00028312041002237 